\title{
SYSTEMATIZATION OF ETHNOECONOMIC VECTORS WITHIN THE CONTEXT OF REGIONAL DEVELOPMENT OF THE KRASNODAR TERRITORY
}

\author{
NIKOLAEVNA KLOCHKO Elena ${ }^{1 *}$, MIKHAILOVICH REZNICHENKO Sergey ${ }^{2}$, \\ VLADIMIROVNA KOVALENKO Lidia ${ }^{3}$
}

${ }^{1}$ Kuban State Agrarian University Named after I.T. Trubilin, Krasnodar, (RUSSIA)

${ }^{2}$ Kuban State Agrarian University Named after I.T. Trubilin, Krasnodar, (RUSSIA)

${ }^{3} 1$ Kuban State Agrarian University Named after I.T. Trubilin, Krasnodar, (RUSSIA)

E-mails:651728@mail.ru;651728@mail.ru;sfmsmu@mail.ru

\begin{abstract}
The research aims to study the role of ethnoeconomy in the regional development of a polyethnic region and the structure of its vectors, which allows considering ethnoeconomy as a structure-forming factor for territories. Methodology: the research was conducted among ethnic entrepreneurs of the Krasnodar Territory. The authors studied the Strategy for Socio-Economic Development of the Krasnodar Territory until 2030 and surveyed 40 ethnic entrepreneurs engaged in ethnic tourism and crafts. Conclusions: according to the authors, the basic ethnoeconomic vectors include ethnic and ethnographic tourism, traditional agriculture and traditional nature management. The ethnic entrepreneurs surveyed indicated several problems in the selected ethnoeconomic vectors, for instance: limited availability of state and municipal programmes that would mobilize additional resources; weak infrastructure of the ethnoeconomic segment of the region, which makes the ethnoeconomic environment less competitive; and low financial resource capacity of the segments of the ethnoeconomic environment. Practical significance: the authors compiled a matrix table presenting the application of methods for regulating the ethnoeconomic vectors of the regional development of the Krasnodar Territory, which allows the authorities of the region to distinguish between the methods of regional ethnoeconomic development in order to control the management situation, adapt instruments and guidelines, and provide tangible support to ethnic entrepreneurs in line with the identified vectors of ethnoeconomic development of the region.
\end{abstract}

Keywords: socio-economic system, polyethnic region, ethnic migrants, economic niches, ethnic entrepreneurship, ethno-economy, ethno-economic paradigm, economic space of the region.

JEL: R11

DOI: $10.5937 /$ intrev2102052

UDC: $334.722(47)$

COBISS.SR-ID 43531017 


\section{INTRODUCTION}

In general, ethnoeconomics is the science about the correlation and interaction of traditions, customs, culture, psychology, ideology, religious views of different ethnos influenced on the productive forces and production relations.

At the current stage, diversification of regional development is a key objective in increasing the socioeconomic efficiency of societal development. Due to this, it is relevant to identify growth opportunities for regional development, both economic and social.

The ethnoeconomic segment of the regional economy has a significant role in developing strategies for optimizing regulatory control of the regional development process. The development of ethnoeconomy can positively affect the self-organization of the regional economy and rational use of natural and other resources.

Naturally, innovative industries have a major impact on the effectiveness of regional development. However, in order to ensure consistent and sustainable development in the long term, it is highly important to encourage the operation of traditional business activities and nature management, which serve as a basis for the ethnoeconomy of the region.

Different specific factors, including natural, geographic, climatic, cultural, and others, define the potential of the ethnoeconomic segment in the regional development of the Krasnodar Territory. The focus of development is on agriculture and recreation, which means that the increase in the rate of socio-economic growth is largely attributed to the activity of the agricultural and the tourist sectors of the economy.

It should be highlighted that management of the ethnoeconomic segment of regional development comprises the resort and recreational sector, traditional agricultural economy and nature management, which allows forming a unique and highly competitive ethnoeconomic environment in the region. However, to achieve it, it is required to reflect systematically on the establishing ethnoeconomic vectors of regional development and design measures to provide resources and state financial backing.

The subject of research is economic relations establishing the formation of ethnoeconomic vectors of regional development in the Krasnodar Territory in the dynamic and transforming socio-economic reality of the present day.

As a conceptual framework of the study, after setting the goal and collecting necessary data and information, it is intended to systematize the main directions of modern ethnoeconomic regional development and provide recommendations for maintaining ethnoeconomic regional development in the Krasnodar Territory.

\section{METHODS}

Data collection is a systematic process of gathering observations or measurements. Data collection allowed us to gain first-hand knowledge and original insights into our research problem. After establishing the aim of the study, we attempted to review relevant articles and sources to reach a reasonable and feasible conclusion.

The basics of the ethnoeconomic factor and its significance in the system of regional development have been discussed in the works by Pechura [1,2], Vitselyarova [3], Markaryan [4], and Horolskaya [5].

The role of the ethnoeconomic aspect in the system of regional development is the main focus of the works by Akpan [6], and Perumal et al. [7].

Let us analyze some of the research mentioned above on the development of regional ethnoeconomy.

The research into ethnic entrepreneurship in Ireland, conducted in 2019 by Birdthistle [8] is of interest. In the course of online interviews, it was found out that ethnic entrepreneurs require considerable support to do business. The existing support measures provided to ethnic entrepreneurs do not always prove effective since people are largely unaware that government programs to support ethnic minorities are available. Ireland has always been a country to give sanctuary to refugees, so in order to support and encourage entrepreneurship in ethnic minorities, it is essential to provide ethnic entrepreneurs with more personalized services to help them do business in another country $[9,10]$.

According to a 2017 research by Z.C. Zhuang [11], not only do the ethnic commercial districts in the Toronto area present Canada's ethnocultural diversity, but they are also important social places, the urban 
landscape of which is formed by ethnic enterprises. The research provides detailed descriptions of social, economic and physical processes associated with establishing ethnic trade points and studies the role that ethnic entrepreneurs have in these processes. Additionally, the research revealed the profound intergroup differences that helped to define the features of the Chinese, South Asian, and Italian business communities in Toronto. It was also identified that ethnic entrepreneurs were the driving force behind social, economic and physical transformations in three districts of the city of Toronto. The empirical data obtained is believed to enable the municipalities of Toronto to design a more flexible and effective support program for ethnic entrepreneurs, which is expected to have a beneficial effect on business climate [12, 13].

Aspiring entrepreneurs tend to face difficulties when starting their own business, which is why, from the perspective of the authors, the most stimulating research that tackles these issues is the study conducted by a group of authors under Ullah et al. [14]. The work presents the analysis of key factors that influence the decision of an ethnic entrepreneur, a migrant from the Indian Subcontinent region, to start a business in Aberdeen, Scotland. The researchers found that it is a positive attitude, self-sufficiency, determination, knowledge of the market and the local business culture, and adequate financial management that allow ethnic entrepreneurs to launch effective business projects $[15,16]$.

The works mentioned above present a variety of approaches to understanding the role of the ethnoeconomic sector in the regional development system. However, they do not give enough attention to some aspects of the formation of ethnoeconomic vectors for regional development with the account of regional socio-economic environment and other specific factors [17, 18].

The present research methodology includes system, monographic, structural, and logical research methods and the method of expert assessment. Each of these methods has been used according to its functionality.

\section{RESULTS AND DISCUSSION}

The long-term forecast for socio-economic development of the Russian Federation for the period up to 2030 states that regional development should be socially oriented and aimed at promoting the interests of various population groups, including those organized along ethnic lines.

Fig. 1 demonstrates the role of traditional economic sectors in the framework for socially oriented regional development. Traditional sectors form the basis for the region's ethnoeconomy and are a key component of the Gross Regional Product (GDP).

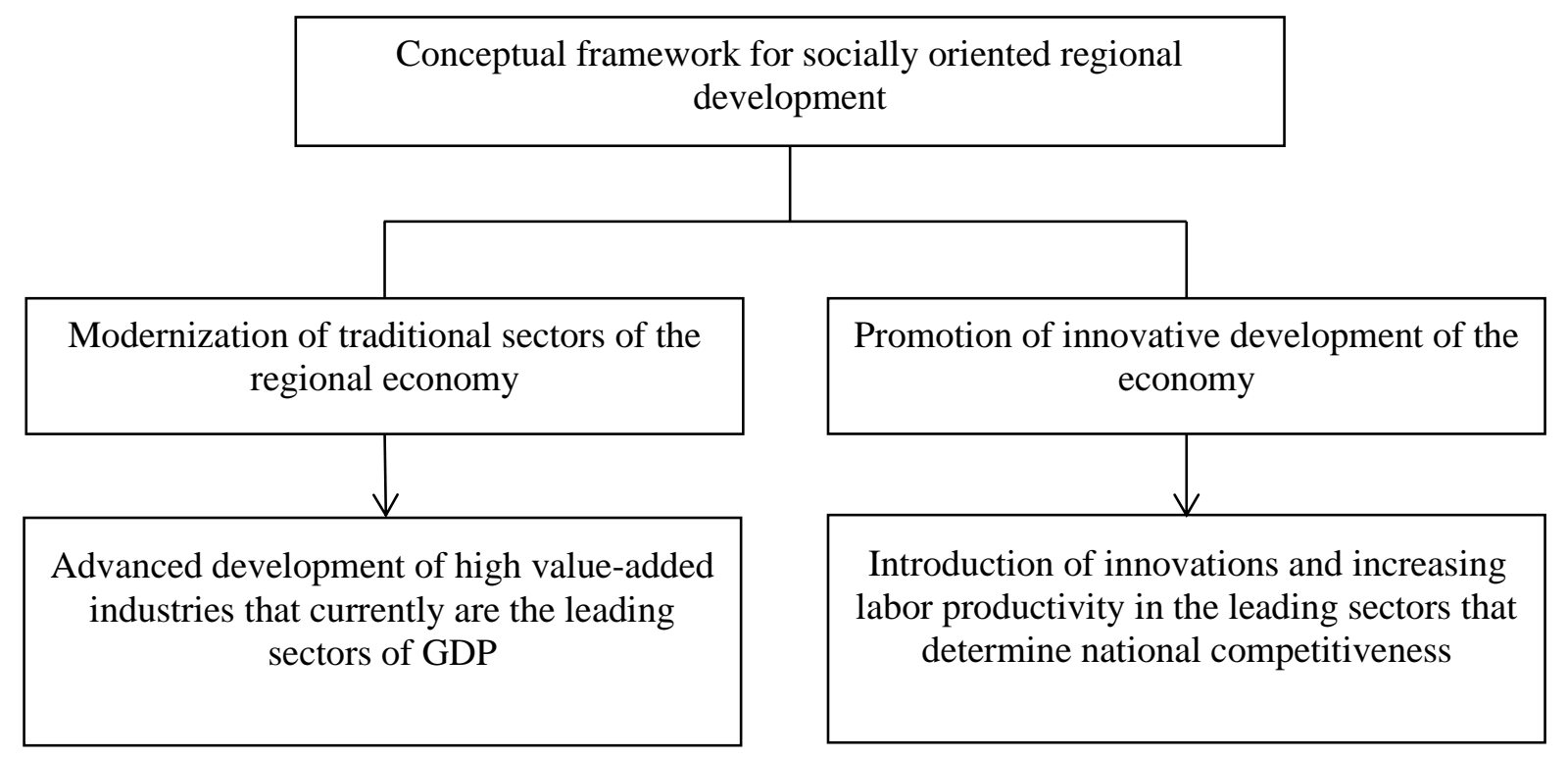

Fig. 1 - The role of traditional economic sectors in the framework for socially oriented regional development 
For the Krasnodar Territory, which historically is an agricultural region, preservation and support of traditional sectors of the regional economy is particularly relevant.

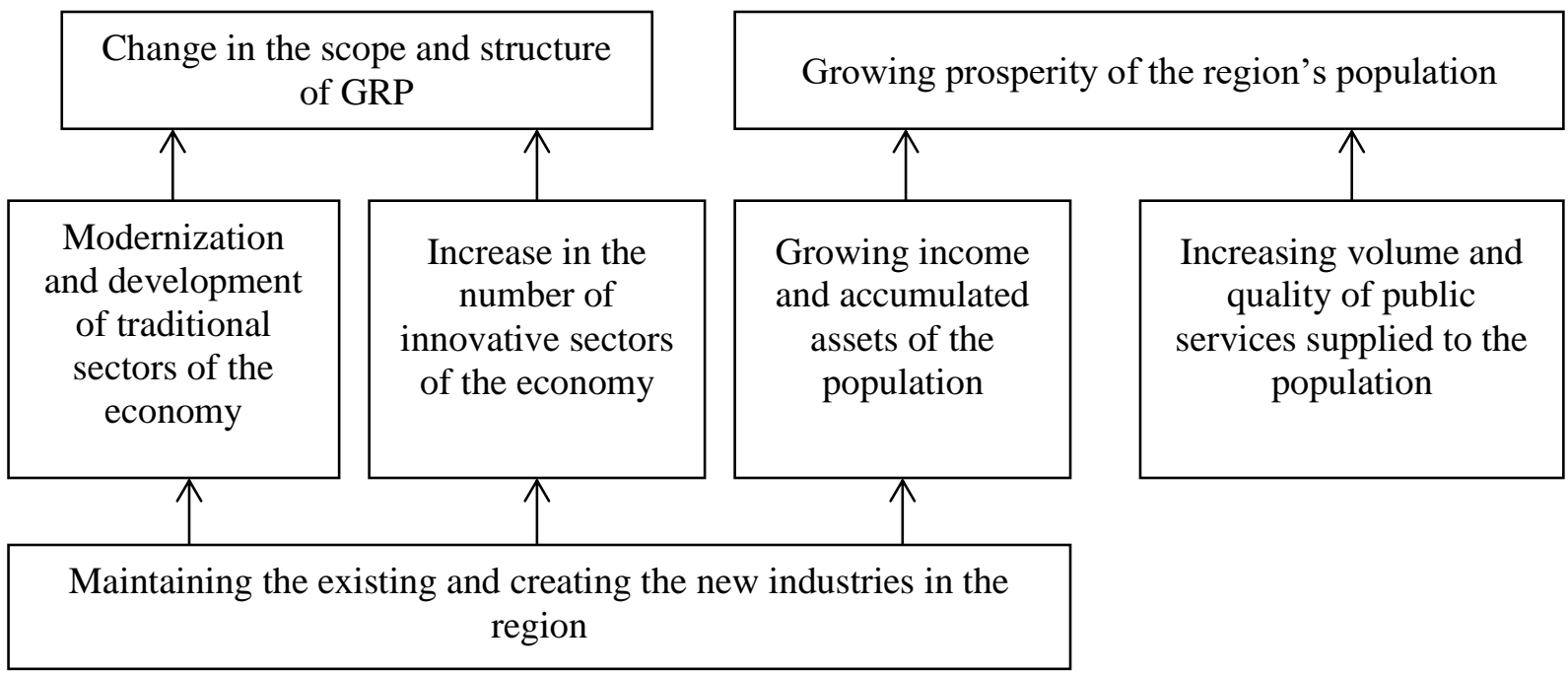

Fig. 2 :Structure of the goals and objectives of regional development in the Krasnodar Territory

As can be seen in Fig. 2, according to the Strategy for socio-economic development of the Krasnodar Territory until 2030, modernization and development of traditional economic sectors is one of the ways to accomplish a major objective of the Strategy, which is to preserve the existing and create the new industries in the region.

Within the context of implementing sanctions policy and developing an import substitution strategy, preservation and targeted transformation of traditional economic sectors is an effective alternative to introducing economic innovations [19].

Following the Strategy for the social and economic development of the Krasnodar Territory until 2030, there are two main areas of ethnoeconomic development in the system of regional governance of the Krasnodar Territory, the characteristics of which are presented in Table 1.

Table 1. Characteristics of the main areas of ethnoeconomic development within the system of regional governance of the Krasnodar Territory

\begin{tabular}{|l|l|}
\hline \multicolumn{1}{|c|}{$\begin{array}{c}\text { Area of ethnoeconomic } \\
\text { development }\end{array}$} & \multicolumn{1}{|c|}{ Content } \\
\hline Socio-economic & $\begin{array}{l}\text { 1. Creating conditions for the development of traditional economic sectors. } \\
\text { 2. Establishing support centres for the subjects of the ethnoeconomic system. } \\
\text { 3. Creating most favourable conditions for ethnic culture development. }\end{array}$ \\
\hline $\begin{array}{l}\text { Organizational and } \\
\text { management }\end{array}$ & $\begin{array}{l}\text { 1. Providing extra financial support for the subjects of the ethnoeconomic system } \\
\text { that preserve the traditional economic activities. } \\
\text { 2. Encouraging both state and local governments to effectively exercise their } \\
\text { authority in promoting ethnoeconomic development of the region. }\end{array}$ \\
\hline
\end{tabular}

For the purpose of systematization of the ethnoeconomic development vectors of the Krasnodar Territory, it is reasonable to differentiate and analyse the subjects of the ethnoeconomy in the Krasnodar Territory by industries (Fig. 3). 


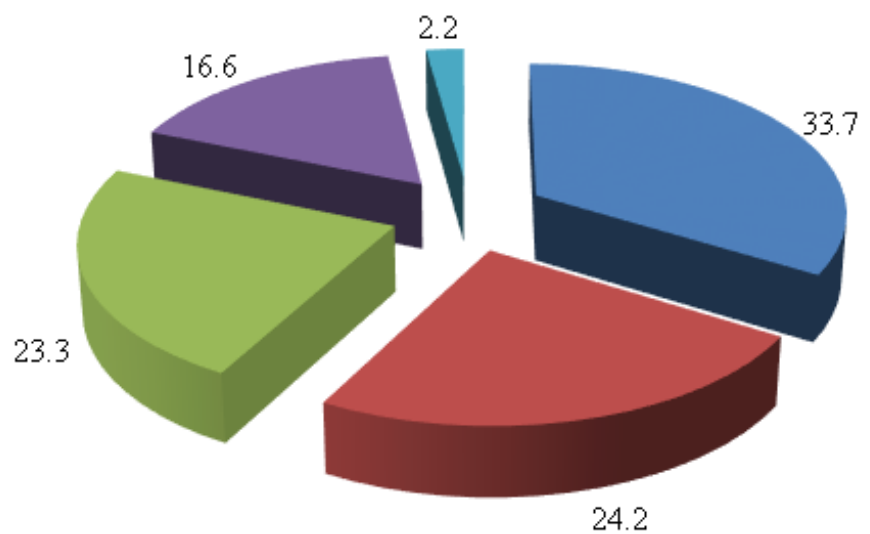

- Ethnic and ethnographic tourism

- Traditional agriculture

- Traditional nature management

- Gastronomy and wine tourism

Arts and crafts

Fig. 3. Distribution of subjects of the ethnoeconomy in the Krasnodar Territory by industries, \%

The diagram shows that a specific feature of the Krasnodar Territory is the growing prevalence of ethnic and ethnographic tourism organizations. A significant percentage is organizations of traditional agriculture and traditional nature management (including hunting, fishing and other types of nature management with ethnic elements involved).

The arts and crafts segment represents a small proportion in the structure of the ethnoeconomic subjects of the Krasnodar Territory. This is mostly due to the complex polyethnic structure of the population of the Krasnodar Territory, without an obvious predominance of arts and crafts of a certain socio-ethnic community.

Thus, ethnic and ethnographic tourism, traditional agriculture, and traditional nature management are considered as the basic segments of the ethnoeconomic development in the system of regional development of the Krasnodar Territory.

In order to identify the specifics of these ethnoeconomic vectors, the authors present the results of an expert assessment (Table 2), where 40 ethnic entrepreneurs of the region acted as experts.

Table 2; Composite score sheet of expert assessment of the maintenance of the basic ethnoeconomic vectors in the system of regional development of the Krasnodar Territory

\begin{tabular}{|c|c|c|c|}
\hline Assessment area & Indicators & $\begin{array}{c}\text { Expert } \\
\text { assessment } \\
\text { total score }\end{array}$ & Result \\
\hline \multirow[t]{3}{*}{$\begin{array}{l}\text { Regulatory } \\
\text { framework }\end{array}$} & $\begin{array}{l}\text { 1. Availability of state (municipal) programmes for } \\
\text { ethnoeconomic regional development }\end{array}$ & 1.9 & Not satisfactory \\
\hline & $\begin{array}{l}\text { 2. Availability of regulatory and legislative documents } \\
\text { for ethnoeconomic regional development }\end{array}$ & 3.3 & Satisfactory \\
\hline & $\begin{array}{l}\text { 3. Availability of guidelines to control ethnoeconomic } \\
\text { regional development }\end{array}$ & 4.0 & Satisfactory \\
\hline \multirow[t]{4}{*}{ Resources } & 1. Availability of land resources & 3.8 & Satisfactory \\
\hline & 2. Availability of ethnoeconomic infrastructure & 2.8 & Not satisfactory \\
\hline & 3. Availability of resources (personnel, energy, etc.) & 3.8 & Satisfactory \\
\hline & 4. Financial resource capacity & 2.6 & Not satisfactory \\
\hline \multirow[t]{3}{*}{$\begin{array}{l}\text { Development } \\
\text { opportunities }\end{array}$} & $\begin{array}{l}\text { 1. Improvement of the quality of goods and services } \\
\text { provided by the subjects of ethnoeconomy }\end{array}$ & 5.4 & Good \\
\hline & 2. Mass consumption of ethnoeconomic products & 7.0 & Good \\
\hline & $\begin{array}{l}\text { 3. Import substitution through traditional forms of } \\
\text { agriculture }\end{array}$ & 5.1 & Satisfactory \\
\hline
\end{tabular}


The results of expert assessment of the maintenance of the basic ethnoeconomic vectors in the system of regional development of the Krasnodar Territory demonstrate the following unsatisfactory areas:

- Limited availability of targeted state (municipal) programs for ethnoeconomic regional development aimed at ensuring extra resources;

- Limited availability of ethnoeconomic infrastructure (poor infrastructure negatively affects the general competitiveness of the ethnoeconomic environment);

- Low financial resource capacity of the segments of the ethnoeconomic environment.

In order to increase regional ethnoeconomic development, it is advisable to apply structured development methods (Table 3).

Table 3: Matrix table presenting the application of methods for regulating the ethnoeconomic vectors of the regional development of the Krasnodar Territory

\begin{tabular}{|c|c|c|}
\hline Methods & Exogenous ethnoeconomic development of the region & $\begin{array}{l}\text { Endogenous ethnoeconomic } \\
\text { development of the region }\end{array}$ \\
\hline Stimulating & $\begin{array}{l}\text { 1. Government investment; } \\
\text { 2. Government subsidies; } \\
\text { 3. Government procurement; } \\
\text { 4. Programmes for ethnoeconomic regional } \\
\text { development. }\end{array}$ & $\begin{array}{l}\text { 1. Provision of benefits for the subjects } \\
\text { of the region's ethnoeconomy; } \\
2 \text {. Regional bonuses to subjects of } \\
\text { ethnoeconomy; } \\
\text { 3. Provision of concessional loans in } \\
\text { segments of the ethnoeconomic } \\
\text { environment; } \\
\text { 4. Establishment of special } \\
\text { ethnoeconomic zones. }\end{array}$ \\
\hline Limiting & $\begin{array}{l}\text { 1. Prohibition on construction of new production } \\
\text { enterprise and expansion of the existing ones; } \\
\text { 2. Prohibition on enterprise expansion through } \\
\text { purchasing production facilities; } \\
\text { 3. Introduction of development certificates; } \\
\text { 4. Relocation of state (municipal) enterprises outside } \\
\text { the city borders; } \\
\text { 5. Tightening legal provisions in the field of land use, } \\
\text { environmental protection, and implementation of } \\
\text { environmental regulations and standards. }\end{array}$ & $\begin{array}{l}\text { 1. Increase in land lease tax rates for } \\
\text { enterprises making a negative } \\
\text { environmental impact; } \\
\text { 2. Introduction of stricter fines for } \\
\text { environmental pollution; } \\
\text { 3. Subsidies on deconcentrating of } \\
\text { organizations of traditional agriculture } \\
\text { and nature management. }\end{array}$ \\
\hline
\end{tabular}

The methods for regional ethnoeconomic development need to be differentiated in order to control the management situation and adapt instruments and guidelines.

Considering the assessment of the maintenance of the basic ethnoeconomic vectors in the system of regional development of the Krasnodar Territory, the authors have compiled a matrix table presenting the application of methods for regulating the ethnoeconomic vectors of the regional development of the Krasnodar Territory.

The presented methods are focused on the features of the ethnoeconomic environment of the Krasnodar Territory and the ethnoeconomic vectors of regional development.

\section{CONCLUSION}

As the conducted research has shown, ethnoeconomy has a special role in regional development. It is a structure-forming factor for the agrarian sector of the economy of a polyethnic region; it diminishes the impacts of the crisis and destructive events on the region's economy, helps to reduce the employment strain, and contributes to the preservation of traditions and customs of ethnic groups residing in a particular territory.

However, to have the long-term opportunity to benefit from the ethnoeconomic segment, the regional government should consistently provide support for the ethnoeconomic environment utilizing specially developed state and municipal programs and improve the ethnoeconomic infrastructure, which is expected to encourage the development of ethnic and ethnographic tourism, as well as traditional forms of agriculture and nature management. 
In general, the Krasnodar Territory has considerable potential for ethnoeconomic development. According to the authors of the present article, ethnoeconomy, allows preserving cultural practices and traditions of ethnic groups in the region and increasing its competitive advantages.

\section{ACKNOWLEDGMENTS}

The research was carried out with the financial support of the Kuban Science Foundation in the framework of the scientific project № FNI-GO-20.1/11

\section{REFERENCES}

[1] Pechura, O. V. (2011). Ethno-economy as a strategic resource of social and economic development of the region. Izvestiya of Irkutsk State Economics Academy, 1(34), pp. 34-58.

[2] Pechura, O.V. (2009). The ethno-economic factor in the development of the regional economy. Bulletin of the Ural State University of Economics, 2 (24), pp. 138-143.

[3] Vitselyarova, K. N. (2015). Employment and ethnoeconomy of the region. Concept, 14, pp.28-36.

[4] Markaryan, V. R. (2020). The role of the ethno-economy of the region in the socio-economic development of the Republic of Crimea. Regional Economics and Management, 1 (61), pp. 3-11.

[5] Horolskaya, T. E. (2019). Vector of fundamental ethnoeconomy. Economic Research and Development, 5, pp. 169-173.

[6] Akpan, A. U. (2000). Ethnoeconomics in sustainable agricultural development: The Nigerian case. Journal of Sustainable Agriculture 27 (1), pp. 5-17.https://doi.org/10.1300/J064v17n01_03.

[7] Perumal, S., Othman, A.R. \& Jaganathan, M. (2019). Entrepreneurial orientation and educational levels in malaysian indian ethnic entrepreneurs. Journal of Advanced Research in Dynamical and Control Systems, 11(5 Special Issue), pp. 1628-1633.

[8] Birdthistle, N. (2019). Under the microscope-an examination of the supports for ethnic entrepreneurs in Ireland. Education+ Training. https://doi.org/10.1108/ET-07-2018-0157.

[9] Mahmoudi, M. T., Azar, M., \& Bahrami, R. (2019). The Impact of Organizational Happiness on the Working Life Quality: A Case Study among Isfahan University's Staff. International Journal of Advanced Studies in Humanities and Social Science, 8(3), pp. 255-

265.http://dx.doi.org/10.33945/SAMI/IJASHSS.2019.3.3

[10] Goodarzi, G. R., Bagheri Ragheb, Q., \& Issazadeh, H. (2021). Designing a talent search model in Taekwondo. International Journal of Advanced Studies in Humanities and Social Science, 10(2), pp. 115-128.http://dx.doi.org/10.22034/ijashss.2021.274104.1043.

[11] Zhuang, Z. C. (2017). The intersection of place and ethnic entrepreneurship: the role of ethnic entrepreneurs in the making of three Toronto neighborhoods. Journal of Architectural and Planning Research, p. 1-22. https://www.jstor.org/stable/44987213.

[12] Tarman, B. (2020). Reflecting in the shade of pandemic. Research in Social Sciences and Technology, 5(2),pp. i-iv. https://doi.org/10.46303/ressat.05.02.ed

[13] Belousova, M., Aleshko, R., Zakieva, R., Karabasheva, M., Gorovoy, S., \& Kozhemov, S. (2021). Development of equipment management system with monitoring of working characteristics of technological processes. Journal of Applied Engineering Science, 19(1), pp. 186192.https://doi.org/10.5937/jaes0-28855.

[14] Ullah, F., Rahman, M. Z., Smith, R., \& Beloucif, A. (2016). What influences ethnic entrepreneurs' decision to start-up: Some evidence from Aberdeen, Scotland. Journal of small business and enterprise development. https://doi.org/10.1108/JSBED-12-2015-0182.

[15] Prodanova, N. A., Savina, N. V., Dikikh, V. A., Enina, Y. I., Voronkova, O. Y., \& Nosov, V. V. (2020). Features of the coherent presentation of information in order to prepare integrated corporate reporting. Entrepreneurship and Sustainability Issues, 7(3), p. 2227.http://doi.org/10.9770/jesi.2020.7.3(54).

[16] Volkova, P., Luginina, A., Saenko, N., \& Samusenkov, V. (2020). Virtual Reality: Pro et Contra. Journal of Social Studies Education Research, 11(4), pp. 190203.https://www.learntechlib.org/p/218544/. 
[17] Magsumov, T. A., \& Grakhova, S. I. (2020). Representation of the History of the Provincial Merchants of Late Imperial Russia in the Contemporaries' Everyday Narrative. Былые годы. Российский исторический журнал, (56), pp. 871-877. http://doi.org/10.13187/bg.2020.2.871.

[18] Yemelyanov, V., Tochilkina, T., Vasilieva, E., Nedelkin, A., \& Shved, E. (2018, October). Computer diagnostics of the torpedo ladle cars. In AIP Conference Proceedings (Vol. 2034, No. 1, p. 020008). AIP Publishing LLC. http://doi.org/10.1063/1.5067351.

[19] Korableva, O., Durand, T., Kalimullina, O., \& Stepanova, I. (2019, March). Studying user satisfaction with the MOOC platform interfaces using the example of coursera and open education platforms. In Proceedings of the 2019 International Conference on Big Data and Education (pp. 2630).http://doi.org/10.1145/3322134.3322139.

\section{Article history:}

Received 10 May 2021

Accepted 25 June 2021 